\title{
INCREASING GRAIN YIELD OF SUBMERGENCE-TOLERANT RICE (ORYZA SATIVA L.) THROUGH APPROPRIATE NUTRIENT MANAGEMENT
}

\author{
HTwe, T. ${ }^{1}$ - Techato, K. $.^{1,2}-$ ChOtikARN, P. ${ }^{3,4}-$ SinUtoK, S. ${ }^{1,3^{*}}$ \\ ${ }^{1}$ Faculty of Environmental Management, Prince of Songkla University, 90110 Songkhla, Thailand \\ ${ }^{2}$ Environmental Assessment and Technology for Hazardous Waste Management Research Center, \\ Prince of Songkla University, 90110 Songkhla, Thailand \\ ${ }^{3}$ Coastal Oceanography and Climate Change Research Center, Prince of Songkla University, \\ Songkhla, 90110 Thailand \\ ${ }^{4}$ Marine and Coastal Resources Institute, Prince of Songkla University, 90110 Songkhla, Thailand \\ *Corresponding author \\ e-mail: ssutinee@gmail.com; phone: +66-74-286-847; fax:+66-74-429-758 \\ (Received 21 $1^{\text {st }}$ Aug 2019; accepted $15^{\text {th }}$ Nov 2019)
}

\begin{abstract}
Flooding is one of the environmental stresses that cause a reduction in rice yield and the effect varies between rice varieties. This study aimed to investigate the response of different rice varieties (Hnan Gar, Swarna-Sub1, Bio-6, and Bio-8) to the application of various combinations of nutrient doses (110:0:75, 110:50:0, 110:50:75, 110:80:75 and 110:50:110 of $\mathrm{N}: \mathrm{P}_{2} \mathrm{O}_{5}: \mathrm{K}_{2} \mathrm{O}$ kg ha ${ }^{-1}$ ) under natural submergence conditions in Myanmar. The survival percentages of the different rice genotypes were found not to be significantly varied after 20 days of submergence. Swarna-Sub1 and Bio-8 produced lower underwater shoot elongation, which tended to save energy to be used for later growth, and this resiliency contributed to higher grain yield. Varying the fertilizer application rates produced no significant effect on the percentage of shoot elongation. The Swarna-Sub1 and Bio-8 varieties produced much higher yields compared to Hnan Gar and Bio-6 as a result of a higher filled grain percentage and panicle number $\mathrm{m}^{-2}$. In addition, fertilizing with a dosage of 110:50:110 $\mathrm{kg} \mathrm{ha}^{-1}\left(\mathrm{~N}_{\mathrm{P}} \mathrm{P}_{2} \mathrm{O}_{5}: \mathrm{K}_{2} \mathrm{O}\right)$ provided better crop performance and higher yield. These results demonstrate that appropriate nutrient management by combining tolerant varieties is able to help in the mitigation of the adverse effect of submergence stress.
\end{abstract}

Keywords: survival, shoot elongation, nutrient, submergence, Myanmar

\section{Introduction}

Flooding is one of the abiotic stresses that cause severe rice yield reduction in Southeast Asia and threaten global food security (FAO, 2016; Yin et al., 2017). Flooding can be categorized into water logging and submergence. Water logging is a condition in which excess water is in the root zone, and water covers on the soil surface while it covers partial or whole plant in submergence condition (Nishiuchi et al., 2012; Sasidhran et al., 2017). The most common and damaging type of submergence which can occur during the vegetative growth of rice is short-term complete inundation (generally less than 2 weeks), also referred to as a flash flood. Grain yield in rainfed lowland rice is constantly challenged by this type of flooding (Iftekharuddaula et al., 2016; Pradhan et al., 2019; Gautam et al., 2019), and can result in severe damage and plant mortality if sustained for more than a week. More than 22 million ha of rainfed lowland rice are affected by submergence in Asia (Gautam et al., 2014a). The FAO (2015) estimated that USD 7.8 billion worth of crops were damaged by major floods 
around the world between 2003 and 2013. Further, in the so-called rice bowl of Myanmar, the Ayeyarwaddy delta, in which the research reported in this paper was conducted, which covers a total of 2.89 million ha each year, as much as 371990 ha are inundated because of seasonal heavy rainfall and the low lying topography (FAO/WFP, 2016). The extent of damage to rice crops caused by complete submergence during their vegetative stage depends on environmental conditions, such as higher temperatures, greater water turbidity, and lower solar radiation, which worsen the severity of the stress (Das et al., 2009; Ye et al., 2018a, b).

Energy shortage caused by anoxia may lead to reduced nutrient uptake by plants, resulting in the cessation of root elongation, leading to pronounced root injury and death of the tips (Bui et al., 2019; Liu et al., 2015; Singh et al., 2014). Moreover, the plant hormone, ethylene accumulates under submergence conditions because its diffusive escape is slower than the synthesis induced by flooding. Several researchers have reported that ethylene promotes internode elongation, chlorophyll degradation and leaf senescence, causing a reduction in photosynthetic carbon fixation during and after submergence (Ella et al., 2003; Jackson, 2008; Yin et al., 2017). Both the excessive use of energy for shoot elongation and the reduction in carbon fixation during submergence accelerate the depletion of carbohydrate. This leads to the increased mortality of submerged plants (Das et al., 2005; Bui et al., 2019; Ye et al., 2018b). In addition, chlorophyll and non-structural carbohydrate retention after submergence has been found to be positively correlated with plant survival (Gautam et al., 2014a).

The mechanism of plant adaptation to flooding depends on the water regime. In deep water areas, internode elongation is necessary to maintain portions of foliage above the water surface for photosynthesis and oxygen transport. On the other hand, reduced elongation is desirable during flash floods since stem or internode elongation may compete with the plant's maintenance processes for energy, and as a result, reduce the chances of survival during flash floods (Bui et al., 2019; Ram et al., 2002). Das et al. (2005) also reported that the survival of seedlings is negatively correlated with stem elongation.

Although traditional cultivars are moderately tolerant to complete submergence, their yield potential is lower (Singh et al., 2014). Gribaldi et al. (2017) stated that fertilizing with half dose of $\mathrm{N}$ and the remaining half at 42 days after planting gave better crop performance and higher yield. Additional potassium and nitrogen application postsubmergence has been noted to increase their survival and yield (Dwivedi et al., 2018). However, farmers in flood-prone area usually use only nitrogenous fertilizer and small amount of phosphorus and potassium sources (FAO/WFP, 2016; Soni and Soe, 2016). In view of this, proper nutrient management is vital for achieving better performance from submergence-tolerant rice varieties, and there is limited information available regarding the appropriate application rate of nutrients in specific areas under natural conditions. Thus, the aim of the research reported herein was to establish the most suitable fertilizer application rate to increase the grain yield of rice in flash flood-prone areas along with the most tolerant genotypes.

\section{Materials and methods}

This research was conducted between June and October 2015 at Thayaungchaung Seed Farm in the Ayeyarwaddy Region, in lower Myanmar (GPS coordinate: $16^{\circ} 45^{\prime}$ 41.2" N, 94 44' 54.1'E, Fig. 1). The research employed a split plot design with three 
replications. The main factor tested was the nutrient application rate, as follows (all figures $\mathrm{N}: \mathrm{P}_{2} \mathrm{O}_{5}: \mathrm{K}_{2} \mathrm{O}, \mathrm{kg} \mathrm{ha}^{-1}$ ): $\mathrm{N}_{1}=$ control (no fertilizer application), $\mathrm{N}_{2}=110: 0: 75$, $\mathrm{N}_{3}=110: 50: 0, \mathrm{~N}_{4}=110: 50: 75, \mathrm{~N}_{5}=110: 80: 75$ and $\mathrm{N}_{6}=110: 50: 110$, and the sub-factor investigated was the rice variety, as follows: $\mathrm{V}_{1}=$ Hnan Gar, $\mathrm{V}_{2}=$ Swarna-Sub1 (local name Yemyoke Khan 1), $\mathrm{V}_{3}=$ Bio- $6, \mathrm{~V}_{4}=$ Bio-8. The seeds were soaked for $24 \mathrm{~h}$ on $27^{\text {th }}$ June, 2015 and incubated for $24 \mathrm{~h}$. Then, the pre-germinated seeds were carefully sown on raised bed. Care and management of seed beds were done as per standard method. Twenty seven-day old seedlings were transplanted to the main field. The spacing was $20 \mathrm{~cm} \times 15 \mathrm{~cm}$ with 2-3 seedlings per hill. Main plots (fertilizer treatments) were separated by bunds of $0.30 \mathrm{~m}$ width and $0.30 \mathrm{~m}$ height, and there was a $1 \mathrm{~m}$ wide alley between the bunds (Pimratch et al., 2015; Atapattu et al., 2018). The plots were subdivided into four unbunded subplots for variety treatments. Each subplot occupied $7.35 \mathrm{~m}^{2}$. The seed source of the Swarna-Sub1 and Hnan Gar was Thayaungchaung Seed Farm and that of Bio-8 and Bio-6 was Aung Myay Ya Seed Farm. Table 1 shows the soil properties of the experimental site. All the doses of triple super phosphate $\left(\mathrm{Ca}\left(\mathrm{H}_{2} \mathrm{PO}_{4}\right)_{2}\right.$; source of $\left.\mathrm{P}\right)$ and potassium chloride $(\mathrm{KCL}$; source of $\mathrm{K})$, and $25 \%$ of the dose of urea $\left(\mathrm{CO}\left(\mathrm{NH}_{2}\right)_{2}\right.$; source of $\left.\mathrm{N}\right)$ were applied during final land preparation of the main field. Of the remaining $\mathrm{N}$ dose, $50 \%$ was added at the maximum tillering stage and $25 \%$ at the panicle ignition stage.

Table 1. Mean values of soil characteristics from experimental field $(n=20)$

\begin{tabular}{c|c}
\hline Characteristics & Mean \\
\hline Soil pH & 4.69 \\
Total N (\%) & 0.24 \\
Available P (ppm)(Bray) & 0.90 \\
Extractable K (meq/100 g soil) & 0.45 \\
Soil texture & Silty clay \\
\hline
\end{tabular}

Meteorological data during the experiment were recorded in Thayaungchaung Seed Farm. Mean daily temperature was from 20 to $37^{\circ} \mathrm{C}$ during the experiment. As a result of successive heavy rain and overflow of river, accumulated water in upstream brought to flood the experimental field from 7 to 27 days after transplanting the seedlings (see Fig. 2) and flooding occurred for 20 days to a depth of between 35 and $60 \mathrm{~cm}$ (Fig. 3). After that, complete submergence was not occurred although it rained fairly.

The plant height was measured from the base of the plant to the longest leaf tip before and after submergence at vegetative stage. It was measured from the base of the plant to the tip of longest panicle at harvesting stage. In order to calculate the underwater shoot elongation, the height before submergence was subtracted from the height after submergence and expressed as a percentage of the plant height before submergence. Surviving plants with at least one new leaf were recorded 10 days after the recession of water and the survival was expressed as a percentage of the number of plants before flooding.

Twelve hills from each sub-plot were randomly selected at harvest time for the determination of the plant height and yield components such as filled grain percentage, 1000-grain weight, and spikelets per panicle. The whole sub-plot except two border rows was harvested, threshed, dried (to a 14\% moisture content), and the grain yield was recorded and converted to yield of $\mathrm{kg}$ per hectare. 


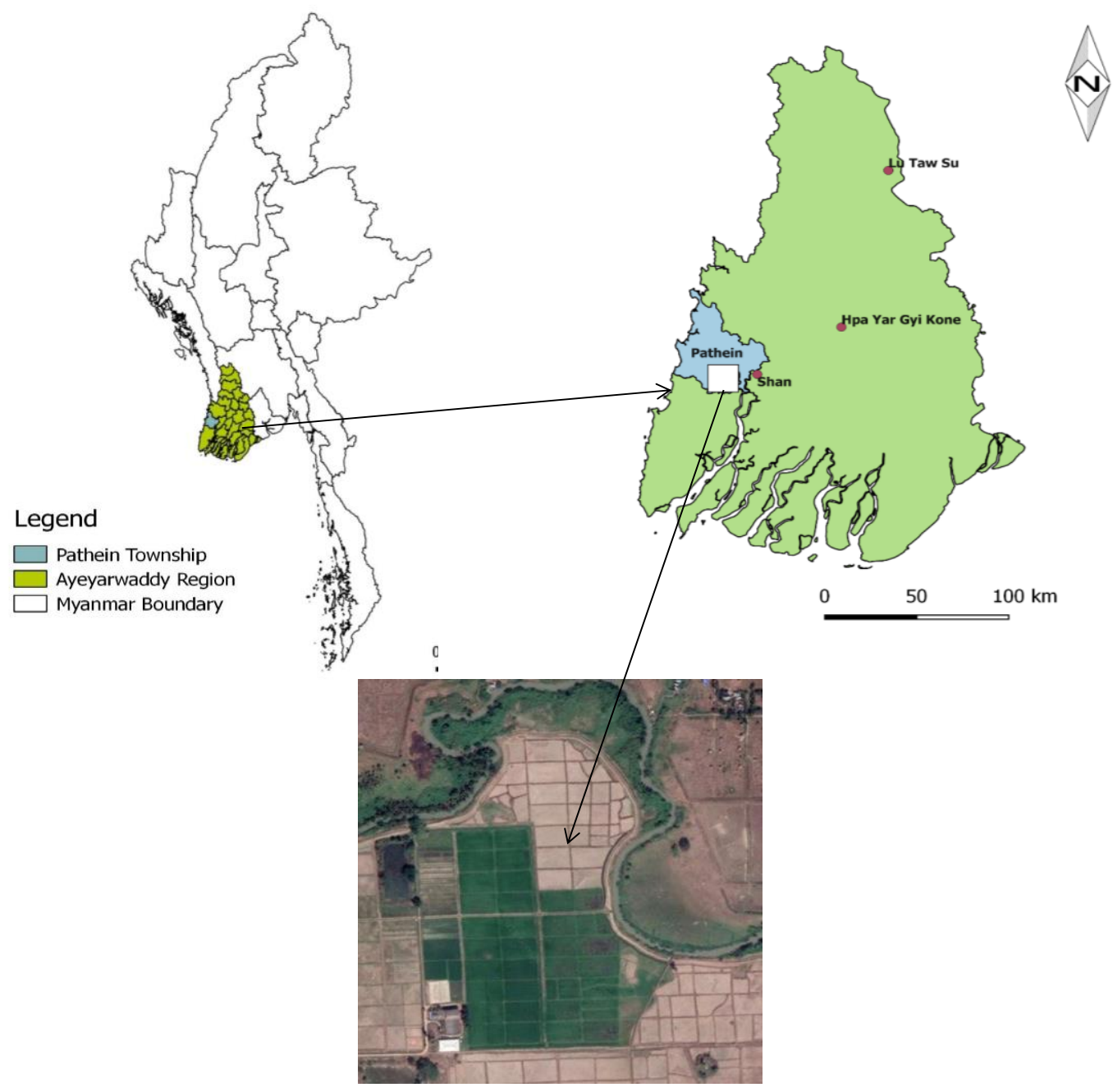

Figure 1. Map showing experimental site in Myanmar

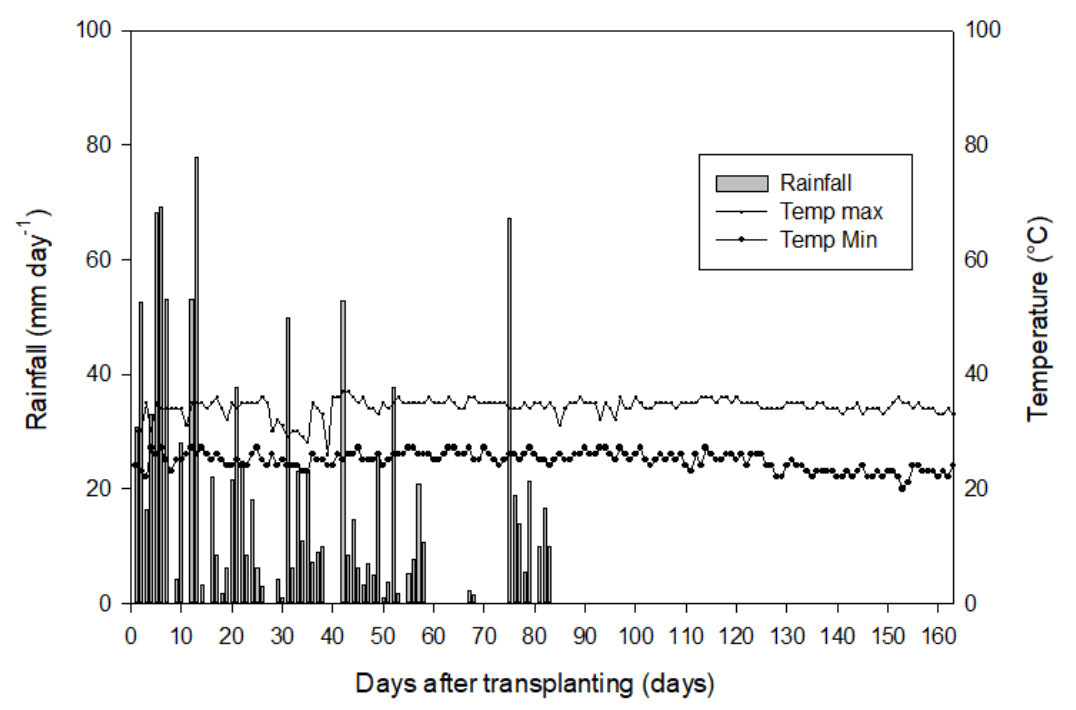

Figure 2. Mean daily maximum and minimum temperature $\left({ }^{\circ} \mathrm{C}\right)$ and rainfall (mm) during experiment 


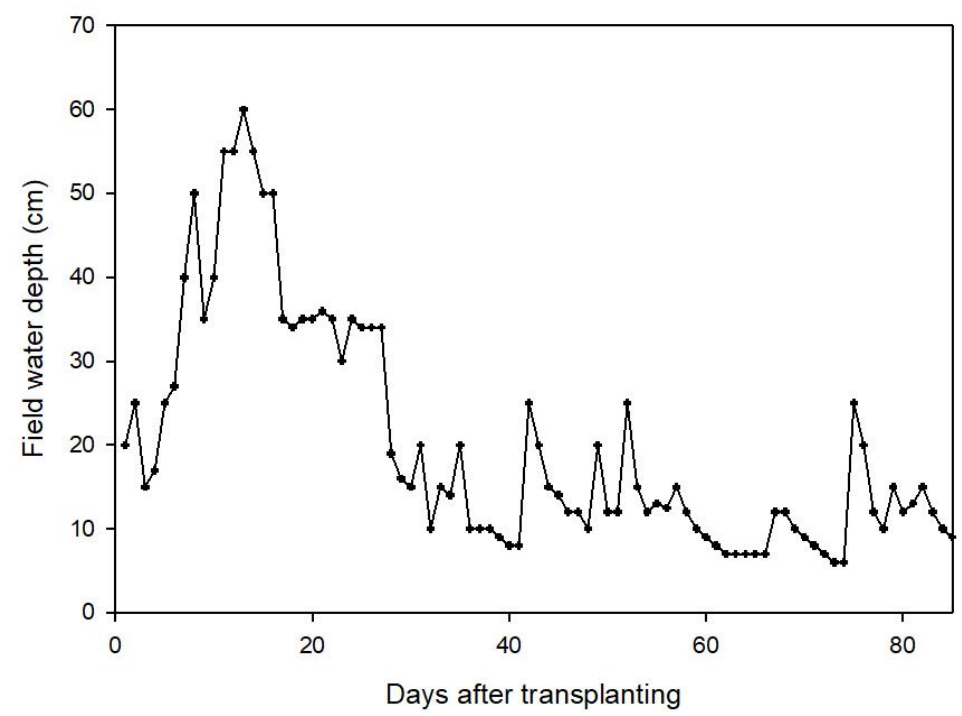

Figure 3. Field water depth during heavy rain at the experimental site, Myanmar

\section{Statistical analysis}

To test for significant differences in rice growth parameters among the different fertilizer treatments and rice varieties, two-way analysis of variance (ANOVA) was employed using the SPSS statistical package (SPSS Statistics Bass 17.0 for Windows EDU). All tests were performed with a significant level of $95 \%$, and Tukey's honestly significant difference post-hoc test was used to identify the statistically distinct groups.

\section{Results}

\section{Effect of submergence and nutrient application on survival and under-water shoot elongation}

The Hnan Gar variety showed higher plant survival than the other varieties; however, the differences were not significant $(\mathrm{P}>0.05)$. Applying fertilizer at different rates also had no significant effect on survival when the rice experienced flooding to a depth of 35$60 \mathrm{~cm}$ starting from 7 days after transplanting for 20 days (Table 2). The Hnan Gar variety was taller than the other three varieties tested before submergence $(\mathrm{P}<0.001)$. The shortest plant height was observed in Bio-8 although this was not significantly different from the heights of Swarna-Sub1 and Bio-6. The individual effect of fertilizer application and its interaction with the rice variety variable was not significant $(\mathrm{P}>0.05)$. A similar trend was noted at desubmergence. All the varieties revealed submergence-induced shoot elongation. However, the Hnan Gar variety showed a significantly higher elongation percentage under water than those of Swarna-Sub1 and Bio-8 $(\mathrm{P}<0.001)$. There were no significant differences $(\mathrm{P}>0.05)$ in the percentage shoot elongation during submergence based on the various rates of fertilizer application (Fig. 4).

\section{Effect of submergence and nutrient application rates on plant height at harvesting time and days to maturity of Hnan Gar, Swarna-Sub1, Bio-6 and Bio-8}

Local variety was significantly taller than those of other tested varieties $(\mathrm{P}<0.001)$ while the heights of Swarna-Sub1, Bio-6 and Bio-8 were statistically similar. The effect 
of fertilizer application rates on plant height can be seen only between the control and the fertilizer applied treatments. The crop duration of Hnan Gar variety was significantly longer than those of other three varieties $(\mathrm{P}<0.001)$. The shortest crop duration was occurred in Bio-6, followed by Swarna-Sub1, Bio-8 and Hnan Gar variety (Table 3).

Table 2. Survival \% of different rice genotypes (Mean $\pm S E)$ under varying fertilizer application rates after 20 days of submergence

\begin{tabular}{c|c|c|c|c|c|c}
\hline $\mathbf{T}$ & $\mathbf{N}_{\mathbf{1}}$ & $\mathbf{N}_{\mathbf{2}}$ & $\mathbf{N}_{\mathbf{3}}$ & $\mathbf{N}_{\mathbf{4}}$ & $\mathbf{N}_{\mathbf{5}}$ & $\mathbf{N}_{\mathbf{6}}$ \\
\hline $\mathrm{V}_{1}$ & $66.11 \pm 0.36$ & $82.5 \pm 5.53$ & $69.58 \pm 3.6$ & $59.03 \pm 4.93$ & $69.58 \pm 6.26$ & $73.75 \pm 7.81$ \\
$\mathrm{~V}_{2}$ & $57.64 \pm 1.44$ & $76.11 \pm 5.54$ & $56.39 \pm 3.6$ & $52.22 \pm 3.73$ & $58.33 \pm 4.57$ & $63.47 \pm 2.41$ \\
$\mathrm{~V}_{3}$ & $61.94 \pm 0.24$ & $79.03 \pm 5.77$ & $66.67 \pm 5.24$ & $55.28 \pm 5.41$ & $64.17 \pm 2.76$ & $69.44 \pm 5.77$ \\
$\mathrm{~V}_{4}$ & $50.42 \pm 2.16$ & $70.39 \pm 4.5$ & $51.81 \pm 6.25$ & $63.61 \pm 2.52$ & $58.89 \pm 1.32$ & $63.47 \pm 6.13$ \\
\hline $\mathrm{T}=$ Treatment, $\mathrm{V}_{1}=$ Hnan Gar, $\mathrm{V}_{2}=$ Swarna-Sub1, $\mathrm{V}_{3}=$ Bio-6, $\mathrm{V}_{4}=$ Bio-8. & $\mathrm{N}_{1}=$ control, \\
$\mathrm{N}_{2}=110: 0: 75, \mathrm{~N}_{3}=110: 50: 0, \mathrm{~N}_{4}=110: 50: 75, \mathrm{~N}_{5}=110: 80: 75, \mathrm{~N}_{6}=110: 50: 110, \mathrm{~N}: \mathrm{P}_{2} \mathrm{O}_{5}: \mathrm{K}_{2} \mathrm{O}$ kgha $\left.^{-1}\right)$
\end{tabular}

Table 3. Effect of different nutrient application rates on plant height at harvesting time and days to maturity of Hnan Gar, Swarna-Sub1, Bio-6 and Bio-8 after being submerged for 20 days

\begin{tabular}{c|c|c}
\hline Treatments & Plant height (cm) & Days to maturity \\
\hline Variety (V) & & \\
Hnan Gar (local variety) & $160.00 \mathrm{a}$ & $172.22 \mathrm{a}$ \\
Swarna-Sub1 & $112.92 \mathrm{~b}$ & $160.44 \mathrm{~b}$ \\
Bio-6 & $112.78 \mathrm{~b}$ & $128.00 \mathrm{c}$ \\
Bio-8 & $113.47 \mathrm{~b}$ & $162.17 \mathrm{~b}$ \\
\hline Nutrient & & \\
Application (N) kg ha-1 & & \\
(N:P2: $\left.\mathbf{N}_{5}: K_{2} \mathbf{O}\right)$ & & 156.00 \\
$\mathrm{~N}_{1}(0: 0: 0$, control) & $121.04 \mathrm{~b}$ & 154.75 \\
$\mathrm{~N}_{2}(110: 0: 75)$ & $126.45 \mathrm{a}$ & 155.92 \\
$\mathrm{~N}_{3}(110: 50: 0)$ & $125.00 \mathrm{a}$ & 155.67 \\
$\mathrm{~N}_{4}(110: 50: 75)$ & $125.20 \mathrm{a}$ & 155.42 \\
$\mathrm{~N}_{5}(110: 80: 75)$ & $125.20 \mathrm{a}$ & 156.60 \\
$\mathrm{~N}_{6}(110: 50: 110)$ & $125.83 \mathrm{a}$ & $\mathrm{n}$ \\
$\mathrm{V}$ & $* *$ & $\mathrm{~ns}$ \\
$\mathrm{~N}$ & $* *$ & $\mathrm{~ns}$ \\
$\mathrm{VxN}$ & $\mathrm{ns}$ & \\
\hline
\end{tabular}

Mean values followed by a different letter are significantly different at Tukey's test $(\mathrm{P} \leq 0.05)$. $* *=$ significant difference at $\mathrm{P} \leq 0.01, \mathrm{~ns}=$ not significant difference at $\mathrm{P}>0.05$

\section{Effect of submergence and fertilizer application rates on grain yield and yield attributes of Hnan Gar, Swarna-Sub1, Bio-6 and Bio-8}

Number of spikelets per panicle

Under submergence condition, the highest number of spikelets per panicle was observed in Swarna-Sub1, followed by Bio-8, Hnan Gar and Bio-6 ( $\mathrm{P}<0.001)$. In the case of fertilizer application, there was no significant difference among the treatments (Table 4). 
Table 4. Effect of different nutrient application rates on yield and its components of Hnan Gar, Swarna-Sub1, Bio-6 and Bio-8 after being submerged for 20 days

\begin{tabular}{|c|c|c|c|c|c|}
\hline Treatments & $\begin{array}{c}\text { Filled } \\
\text { grain }(\%)\end{array}$ & $\begin{array}{c}\text { 1000-grain } \\
\text { weight (g) }\end{array}$ & $\begin{array}{l}\text { Spikelets } \\
\text { panicle }^{-1}\end{array}$ & $\begin{array}{c}\text { Panicles } \\
\mathbf{m}^{-2}\end{array}$ & $\begin{array}{c}\text { Yield } \\
\left(\mathrm{t} \mathrm{ha}^{-1}\right)\end{array}$ \\
\hline $\begin{array}{c}\text { Variety (V) } \\
\text { Hnan Gar (local variety) } \\
\text { Swarna-Sub1 } \\
\text { Bio-6 } \\
\text { Bio-8 }\end{array}$ & $\begin{array}{l}80.70 \mathrm{~b} \\
88.37 \mathrm{a} \\
70.07 \mathrm{c} \\
86.65 \mathrm{a}\end{array}$ & $\begin{array}{l}20.28 \mathrm{~b} \\
20.06 \mathrm{~b} \\
25.82 \mathrm{a} \\
20.36 \mathrm{~b}\end{array}$ & $\begin{array}{l}121.17 \mathrm{~b} \\
170.00 \mathrm{a} \\
108.50 \mathrm{~b} \\
168.67 \mathrm{a}\end{array}$ & $\begin{array}{c}170.61 \mathrm{c} \\
255.92 \mathrm{ab} \\
232.32 \mathrm{~b} \\
266.81 \mathrm{a}\end{array}$ & $\begin{array}{l}2.35 \mathrm{~b} \\
4.22 \mathrm{a} \\
2.20 \mathrm{~b} \\
4.27 \mathrm{a}\end{array}$ \\
\hline $\begin{array}{c}\text { Nutrient } \\
\text { Application (N) kg ha-1 } \\
\left(\mathbf{N}_{\mathbf{1}} \mathbf{P}_{2} \mathbf{O}_{5}: \mathbf{K}_{2} \mathbf{O}\right) \\
\mathrm{N}_{1}(0: 0: 0 \text {, control) } \\
\mathrm{N}_{2}(110: 0: 75) \\
\mathrm{N}_{3}(110: 50: 0) \\
\mathrm{N}_{4}(110: 50: 75) \\
\mathrm{N}_{5}(110: 80: 75) \\
\mathrm{N}_{6}(110: 50: 110) \\
\mathrm{V} \\
\mathrm{N} \\
\mathrm{VxN}\end{array}$ & $\begin{array}{c}79.58 \mathrm{bc} \\
83.16 \mathrm{ab} \\
78.71 \mathrm{c} \\
81.24 \mathrm{abc} \\
82.06 \mathrm{abc} \\
83.93 \mathrm{a} \\
* * \\
* \\
* *\end{array}$ & $\begin{array}{c}21.36 \mathrm{~b} \\
21.72 \mathrm{ab} \\
21.46 \mathrm{~b} \\
21.61 \mathrm{ab} \\
21.67 \mathrm{ab} \\
21.97 \mathrm{a} \\
* * \\
* \\
* *\end{array}$ & $\begin{array}{c}140.33 \\
134.50 \\
147.08 \\
141.33 \\
136.67 \\
152.58 \\
* * \\
\text { ns } \\
\text { ns }\end{array}$ & $\begin{array}{c}228.69 \\
234.14 \\
228.69 \\
228.69 \\
245.14 \\
223.24 \\
* * \\
\text { ns } \\
\text { ns }\end{array}$ & $\begin{array}{c}2.87 \mathrm{c} \\
3.45 \mathrm{ab} \\
3.08 \mathrm{bc} \\
3.31 \mathrm{abc} \\
3.31 \mathrm{abc} \\
3.51 \mathrm{a} \\
* * \\
* * \\
\mathrm{~ns}\end{array}$ \\
\hline
\end{tabular}

Mean values followed by a different letter are significantly different at Tukey's test $(\mathrm{P} \leq 0.05)$. $* *=$ significant difference at $\mathrm{P} \leq 0.01, *=$ significant difference at $\mathrm{P} \leq 0.05$, ns $=$ not significant difference at $\mathrm{P}>0.05$

\section{Number of panicles per $m^{2}$}

The local variety, Hnan Gar produced the lowest number of panicles per $\mathrm{m}^{2}$, which was significantly different from Swarna-Sub1, Bio-6 and Bio-8 $(\mathrm{P}<0.001)$. The highest number of panicles per $\mathrm{m}^{2}$ was observed in Swarna-Sub1, followed by Bio-8, and Bio-6. The effect of different fertilizer application rates on the number of panicles was not significantly different among the treatments.

\section{0-grain weight}

Genotype Bio-6 produced the heaviest thousand-grain weight among the varieties tested $(\mathrm{P}<0.001)$. Hnan Gar, Bio-8 and Swarna-Sub1 had similar thousand-grain weights. In the case of the effect of the fertilizer application rate, $\mathrm{N}_{6}$ produced the heaviest seeds and the difference from other potassium omitting treatments $\left(\mathrm{N}_{1}\right.$ and $\left.\mathrm{N}_{3}\right)$ was significant $\mathrm{P}<0.05$ ). There were no significant differences in seed weight among treatments $\mathrm{N}_{1}, \mathrm{~N}_{2}, \mathrm{~N}_{4}$ and $\mathrm{N}_{5}$. The interaction effect of fertilizer application and variety produced significant differences, showing that the Bio-8 and Hnan Gar varieties were more responsive and produced heavier grain under the $\mathrm{N}_{6}$ treatment.

\section{Filled grain percentage}

The highest filled grain \% was observed in Swarna-Sub1 which was not significantly different from that of Bio-8. On the other hand, the Bio- 6 genotype showed the lowest filled grain percentage after submergence $(\mathrm{P}<0.001)$. In the case of the fertilizer effect, $\mathrm{N}_{6}$ produced significantly higher filled grain percentage than those of the potassium 
omitting treatments $\left(\mathrm{N}_{1}\right.$ and $\left.\mathrm{N}_{3} ; \mathrm{P}<0.05\right)$. The filled grain percentages for the $\mathrm{N}_{2}, \mathrm{~N}_{4}$ and $\mathrm{N}_{5}$ treatments were not significantly different.
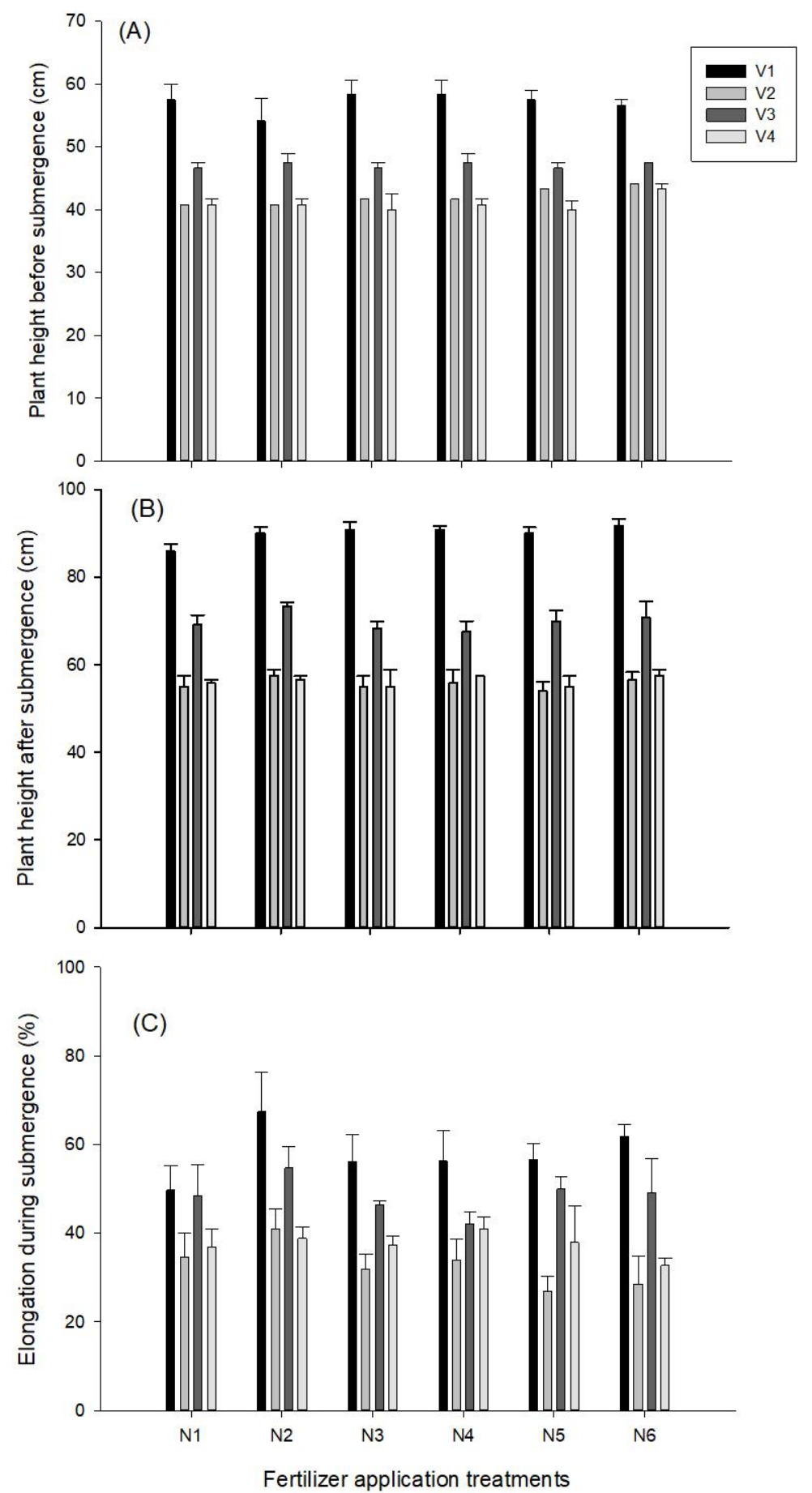

Figure 4. Responses of combination of nutrient application rates and varieties to plant height (A) before submergence (B) after submergence and $(C)$ elongation percentage during submergence. Data are means \pm standard error $(S E)$. Error bars indicate $S E$. $V_{l}=$ Hnan Gar, $V_{2}=$ Swarna-Subl, $V_{3}=$ Bio-6, $V_{4}=$ Bio-8. $N_{1}=$ control, $N_{2}=110: 0: 75, N_{3}=110: 50: 0$, $\left.N_{4}=110: 50: 75, N_{5}=110: 80: 75, N_{6}=110: 50: 110 ; \mathrm{N}^{2} \mathrm{P}_{2} \mathrm{O}_{5}: \mathrm{K}_{2} \mathrm{O} \mathrm{kg} \mathrm{ha}{ }^{-1}\right)$ 


\section{Grain yield $\left(t h a^{-1}\right)$}

The grain yield was higher in Swarna-Sub1 (4.22 t ha-1) and Bio-8 (4.27 $\left.\mathrm{t} \mathrm{ha}^{-1}\right)$ than those of Bio-6 and Hnan Gar $\left(2.20\right.$ and $2.35 \mathrm{t} \mathrm{ha}^{-1}$, respectively; $\left.\mathrm{P}<0.001\right)$ which were almost half those of the two higher yielding varieties. The maximum grain yield was observed in the $\mathrm{N}_{6}$ fertilizer treatment, followed by the $\mathrm{N}_{2}, \mathrm{~N}_{5}$ and $\mathrm{N}_{4}$ treatments. $\mathrm{N}_{3}$ There were no significant differences in grain yield among the control $\left(\mathrm{N}_{1}\right)$ and $\mathrm{N}_{3}, \mathrm{~N}_{4}$ and $\mathrm{N}_{5}$ treatments. The interaction effect of fertilizer application and variety was not significantly different.

\section{Discussion}

The soil test results before the experiment revealed an acid soil with low to moderate content of nitrogen, phosphorus and potassium, suggesting that the optimal application of nutrients could increase performance and yield of the rice plants (Table 1). Flash flood or submergence of rice frequently occurs in monsoon rice production and adversely affects crop establishment and grain yield. In combination with varietal development, submergence tolerance of rice could be manipulated through crop management practices (Sarkar et al., 2014). In the present study, the local variety, Hnan Gar and other three varieties: Swarna-Sub1, Bio-8 and Bio-6 were tested to depict their tolerance capacity of inundation under natural condition.

There were no significant differences observed in the plant survival percentages among the different genotypes under varying fertilizer application rates. Minimizing shoot elongation during complete submergence is a desirable characteristic of rice plants, which can save energy for the regeneration of plant growth after the recession of flood water (Bailey-Serres et al., 2010). On the other hand, varieties which produce greater shoot elongation under flooding have poorer ability to recover quickly after inundation (Jackson and Ram, 2003). In this study, Swarna-Sub1 and Bio-8 exhibited lower shoot elongation percentages in comparison with a local variety, demonstrating a quiescence strategy (Fig. 4). However, no significant differences in shoot elongation percentages were observed based on the different nutrient application treatments. In a previous study, applying post-submergence $\mathrm{N}$ and basal $\mathrm{P}$ was found to decrease the extent of shoot elongation and increase plant survival while the application of $\mathrm{N}, 2$ days prior to submergence increased elongation (Gautam et al., 2014b).

Local variety was the tallest among the tested varieties. The response of plant height to fertilizer application was occurred only between the fertilizers applied treatments and no applied one. Regarding with crop duration, submergence tolerant variety that has shorter days to maturity is a desirable character for increasing cropping intensity in rainfed lowland areas (Iftekharuddaula et al., 2016). In the present study, Bio-6 variety can be harvested about one month earlier than Swarna-Sub1 and Bio-8, while the crop duration of Bio- 6 was about 45 days shorter than that of local variety (Table 3).

The differential performance of cultivars regarding with yield and yield components was observed in this study (Table 4). The grain yields of the Swarna-Sub1 and Bio-8 varieties were close to double those of the Bio- 6 and Hnan Gar varieties and this resulted from their higher filled grain percentage and grain number per panicle following exposure to inundation. It was observed that Swarna-Sub1 and Bio-8 recovered quickly after the recession of the flood water and they also demonstrated higher tillering capacity even after being submerged for 20 days starting from 7 days after transplanting. The early-developed tillers resulted in a higher filled grain 
percentage. According to Gribaldi et al. (2017), submergence-tolerant rice not only survives but also grows quickly after submergence. On the other hand, genotypes without $S U B 1$ have revealed a delay in tiller emergence during the recovery period (Singh et al., 2014).

Appropriate crop and nutrient management increased the grain yield of rice under stagnant flooded condition (Sarangi et al., 2015). In the current experiment, applying fertilizer at the rate of 110:50:110, N: $\mathrm{P}_{2} \mathrm{O}_{5}: \mathrm{K}_{2} \mathrm{O}\left(\mathrm{kg} \mathrm{ha}^{-1}\right)$ produced a higher filled grain percentage and 1000-grain weight leading to a higher grain yield. Similar finding was occurred in the report of Bhowmick et al. (2014), in which, higher seed setting rate contributed to higher grain yield of submergence rice. In addition, filled grain percentage was affected by increase water depth and flooding duration (Zhang et al., $2015)$. In the present study, the treatments in which no potassium was applied $\left(\mathrm{N}_{1}\right.$ and $\mathrm{N}_{3}$ ) adversely affected the yield and its components. This result was supported by the finding of Gautam et al. (2016) which stated that adding sufficient $\mathrm{K}$ can alleviate the impairment of rice due to submergence stress. Potassium has been found to be involved in many abiotic stress toleration processes and contributes to sustainable crop growth, yield and quality, and also influences plant health and reduces environmental risks (Wang et al., 2013). Potassium was sensitive to water logged condition and it affect negatively to the plant growth in flood-prone area. Application of higher dose of potassium to the rice field increased the survival of rice after submergence (Dwivedi et al., 2017). Furthermore, in a previous study, the basal application of $P$ enhanced for the development of effective tillers (Gautam et al., 2015). Therefore, application of proper nutrient management helps in alleviation of damage caused by submergence.

\section{Conclusions}

Higher grain yield was produced by the Swarna-Sub1 and Bio-8 varieties after 20 days of natural flooding, showing their better performance and yield potential. In addition, application of fertilizer at the optimal rate of 110:50:110, $\mathrm{N}: \mathrm{P}_{2} \mathrm{O}_{5}: \mathrm{K}_{2} \mathrm{O} \mathrm{kg} \mathrm{ha}{ }^{-1}$ aided the plants' ability to recover quickly from inundation. The results of this study will be useful in mitigating the adverse effects of inundation on rice grown on low land during the rainy season and increase the potential of submergence-tolerant rice varieties.

It can be concluded that Bio-6 variety can be a good candidate in term of crop duration for promoting cropping intensity while Swarna-Sub1 and Bio-8 varieties are good for offering higher grain output toward global food security. Further studies in different location and rainfall conditions and more seasons of study might be needed.

Acknowledgements. This project was financially supported by Interdisciplinary Graduate School of Energy System (IGS-Energy) scholarship, Faculty of Environmental Management and Graduate School of Prince of Songkla University (PSU). Authors would like to thank to for Michael Guy Currie for English proof. Ms. Than would like to give sincere thanks to the Department of Agriculture, Myanmar for their permission to conduct the experiment and providing for the seed.

\section{REFERENCES}

[1] Atapattu, A. J., Prasantha, B. D. R., Amaratunga, K. S. P., Marambe, B. (2018): Increased rate of potassium fertilizer at the time of heading enhances the quality of direct seeded 
rice. - Chemical and Biological Technologies in Agriculture 5. DOI: 10.1186/s40538018-0136-x.

[2] Bailey-Serres, J., Fukao, T., Ronald, P., Ismail, A., Heuer, S., Mackill, D. (2010): Submergence tolerant rice: SUB1's journey from landrace to modern cultivar. - Rice 31: 138-147.

[3] Bhowmick, M. K., Dhara, M. C., Singh, S., Dar, M. H., Singh, U. S. (2014): Improved management options for submergence-tolerance (sub1) rice genotype in flood-prone rainfed lowlands of West Bengal. - American Journal of Plant Sciences 5: 14-23.

[4] Bui, L. T., Ella, E. S., Dionisio-Sese, M. L., Ismail, A. M. (2019): Morpho-physiological changes in roots of rice seedling upon submergence. - Rice Science 26: 167-177.

[5] Das, K. K., Sarkar, R. K., Ismail, A. M. (2005): Elongation ability and non-structural carbohydrate levels in relation to submergence tolerance in rice. - Plant Science 168: 131136.

[6] Das, K. K., Panda D., Sarkar, R. K., Reddy, J. N., Ismail, A. M. (2009): Submergence tolerance in relation to variable floodwater conditions in rice. - Environmental and Experimental Botany 66: 425-434.

[7] Dwivedi, S. K., Kumar, S., Bhakta, N., Singh, S. K., Rao, K. K., Mishra, J. S., Singh, A. K. (2017): Improvement of submergence tolerance in rice through efficient applicaton of potassium under submergence-prone rainfed ecology of Indo-Gangetic Plain. - Functional Plant Biology 44: 907-916.

[8] Dwivedi, S. K., Kumar, S., Bhakta, N., Srivastava, A. K., Mishra, J. S., Kumar, V., Kumara, B. H., Bhatt, B. P., Singh, S. (2018): Physiological mechanism and nutriment management strategies for flood tolerance in rice grown in lowland flood prone ecosystem. - Journal of Crop Science and Biotechnology 21: 321-333.

[9] Ella, E. S., Kawano, N., Yamauchi, Y., Tanaka, K., Ismail, A. M. (2003): Blocking ethylene perception enhances flooding tolerance in rice seedlings. - Functional Plant Biology 30: 813-819.

[10] FAO (2015): The impact of Natural Hazards and Disasters on Agriculture and Food Security and Nutrition. - FAO, Rome.

[11] FAO (2016): Global Information and Early Warning System on Food and Agriculture. FAO, Rome

[12] FAO/WFP (2016): Special Report by Food and Agriculture Organization of the United Nations, World Food Programmme. - Crop and food security assessment mission to Myanmar. FAO, Rome.

[13] Gautam, P., Nayak, A. K., Lal, B., Bhattacharyya, P., Tripathi, R., Shahid, M., Mohanty, S., Raja, R., Panda, B. B. (2014a): Submergence tolerance in relation to application time of nitrogen and phosphorus in rice (Oryza sativa L.). - Environmental and Experimental Botany 99: 159-166.

[14] Gautam, P., Lal, b., Raja, R., Baig, M. J., Haldar, D., Rath, L., Shahid, M., Tripathi, R., Mohanty, S., Bhattacharyya, P., Nayak, A. K. (2014b): Post-flood nitrogen and basal phosphorus management affects survival, metabolic changes and anti-oxidant enzyme activities of submerged rice (Orzo sativa). - Functional Plant Biology 41: 1284-1294.

[15] Gautam, P., Lal, B., Raja, R., Tripathi, R., Shahid, M., Baig, M. J., Puree, C., Mohanty, S., Nayak, A. K. (2015): Effect of simulated flash flooding on rice and its recovery after flooding with nutrient management strategies. - Ecological Engineering 77: 250-256.

[16] Gautam, P., Lal, B., Tripathi, R., Shahid, M., Baig, M. J., Maharana, S., Puree, C., Nayak, A. K. (2016): Beneficial effects of potassium application in improving submergence tolerance of rice (Oryza sativa L.). - Environmental and Experimental Botany 128: 1830 .

[17] Gautam, P., Lal, B., Nayak, A. K., Tripathi, R., Shahid, M., Meena, B. P., Singh S., Srivastava, A. K. (2019): Nutient management and submergence-tolerant varieties antecedently enhances the productivity and profitability of rice in flood-prone regions. Journal of Plant Nutrition 42: 1913-1927. 
[18] Gribaldi, G., Nurlaili, N., Dewi, N., Danial, E., Sakalena, F., Suwignyo, R. A. (2017): Modified application of nitrogen fertilizer for increasing rice variety tolerance toward submergence stress. - International Journal of Agronomy DOI: 10.1155/2017/9734036.

[19] Iftekharuddaula, K. M., Ahmed, H. U., Ghosal, S., Amin, A., Moni, Z. R., Ray, B. P., Barman, H. N., Siddique, M. A., Collard, B. C. Y., Septiningsih, E. M. (2016): Development of early maturing submergence-tolerant rice varieties for Bangladesh. Field Crops Research 190: 44-53.

[20] Jackson, M. B. (2008): Ethylene-promoted elongation: an adaptation to submergence stress. - Annals of Botany 101: 229-248.

[21] Jackson, M. B., Ram P. C. (2003): Physiological and molecular basis of susceptibility and tolerance of rice plants to complete submergence. - Annals of Botany 91: 227-241.

[22] Liu, G., Li, Y., Fu, X. (2015): Practices to minimize flooding damage to commercial vegetable production. - http://ufdc.ufl.edu/IR00007329/00001.

[23] Nishiuchi, S., Yamauchi, T., Takahashi, H., Kotula, L., Nakazono, M. (2012): Mechanisms for coping with submergence and waterlogging in rice. - Rice 5. DOI: 10.1186/1939-8433-5-2.

[24] Pimratch, S., Butsat, S., Kesmala, T. (2015): Application of blue-green algae and mineral fertilizers to direct seeding lowland rice. - Science Asia 41: 305-314.

[25] Pradhan, S. K., Pandit, E., Pawar, S., Baksh, S. Y., Mukherjee, A. K., Mohanty, S. P. (2019): Development of flash-flood tolerant and durable bacterial blight resistant versions of mega rice variety 'Swarna' through marker-assisted backcross breeding. - Scientific Reports 9: 12810.

[26] Ram, P. C., Singh, B. B., Singh, A. K., Ram, P., Singh, P. N., Singh, H. P., Boamfa, I., Harren, F., Santosa, E., Jackson, M. B., Stter, T. L., Reuss, J., Wade, I. J., Singh, V. P., Singh, R. K. (2002): Submergence tolerance in rainfed lowland rice: physiological basis and prospects for cultivar improvement through marker-aided breeding. - Field Crops Research 76: 131-152.

[27] Sarangi, S. K., Maji, B., Singh, S., Sharma, D. K., Burman, D., Singh, U. S., Ismail, A. M., Haefele, S. M. (2015): Using improved variety and management enhances rice productivity in stagnant flood-affected tropical coastal zones. - Field Crops Research 190: 70-81.

[28] Sarkar, R. K., Das K. K., Panda, D., Reddy, J. N., Patnaik, S. S. C., Patra, B. C., Singh, D. P. (2014): Submergence Tolerance in Rice: Biophysical Constraints, Physiological Basis and Identification of Donors. - Central Rice Research Institute (Indian Council of Agricultural Research), Cuttack.

[29] Sasidharan, R., Bailey-Serres, J., Ashikari, M., Atwell, B. J., Colmer, T. D., Fagerstedt, K., Fukao, T., Geigenberger, P., Hebelstrup, K. H., Hill, R. D., Holdsworth, M. J., Ismail, A. M., Licausi, F., Mustroph, A., Nakazono, M., Pedersen, O., Perata, P., Sauter, M., Shih, M-C., Sorrell, B. K., Striker, G. G., Dongen, J. T. V., Whelan, J., Xiao, S., Visser, E. J. W., Voesenek, L. A. C. J. (2017): Community recommendations on terminology and procedures used in flooding and low oxygen stress research. - New Phytologist 214: 1403-1407.

[30] Singh, S., Mackil, D. J., Ismail, A. M. (2014): Physiological basis of tolerance to complete submergence in rice involves genetic factors in addition to the SUBI gene. - AoB Plants 6: plu060. DOI: 10.1093/aobpla/plu060.

[31] Soni, P., Soe, M. N. (2016): Energy balance and energy economic analyses of rice production system in Ayeyarwaddy Region of Myanmar. - Energy Efficiency 9: 223-237.

[32] Wang, M., Zheng, Q., Shen, Q., Guo, S. (2013): The critical role of potassium in plant stress response. - International Journal of Molecular Sciences 14: 7370-7390.

[33] Ye, X. Q., Zeng, B., Meng, J. L., Wu, M., Zhang, X. P. (2018a): Responses in shoot elongation, carbohydrate utilization and growth recovery of an invasive species to submergence at different water temperatures. - Scientific Reports 8: 306. 
[34] Ye, X. Q., Meng, J. L., Zeng, B., Wu, M. (2018b): Improved flooding tolerance and carbohydrate status of flood-tolerant plant Arundinella anomala at lower water temperature. - PloS One 13. https://doi.org/10.1371/journal.pone.0192608.

[35] Yin, C-C., Zhao, H., Ma, B., Chen, S-Y., Zhang, J-S. (2017): Diverse roles of ethylene in regulating agronomic traits in rice. - Frontiers in Plant Science 8: 1676.

[36] Zhang, Y., Wang, Z., Li, L., Zhou, Q., Xiao, Y., Wei, X., Zhou, M. (2015): Short-term complete submergence of rice at the tillering stage increases yield. - PLoS One. DOI: 10.1371/journal.pone.0127982.

\section{APPENDIX}

Appendix 1. Submergence condition of experimental field after heavy rain

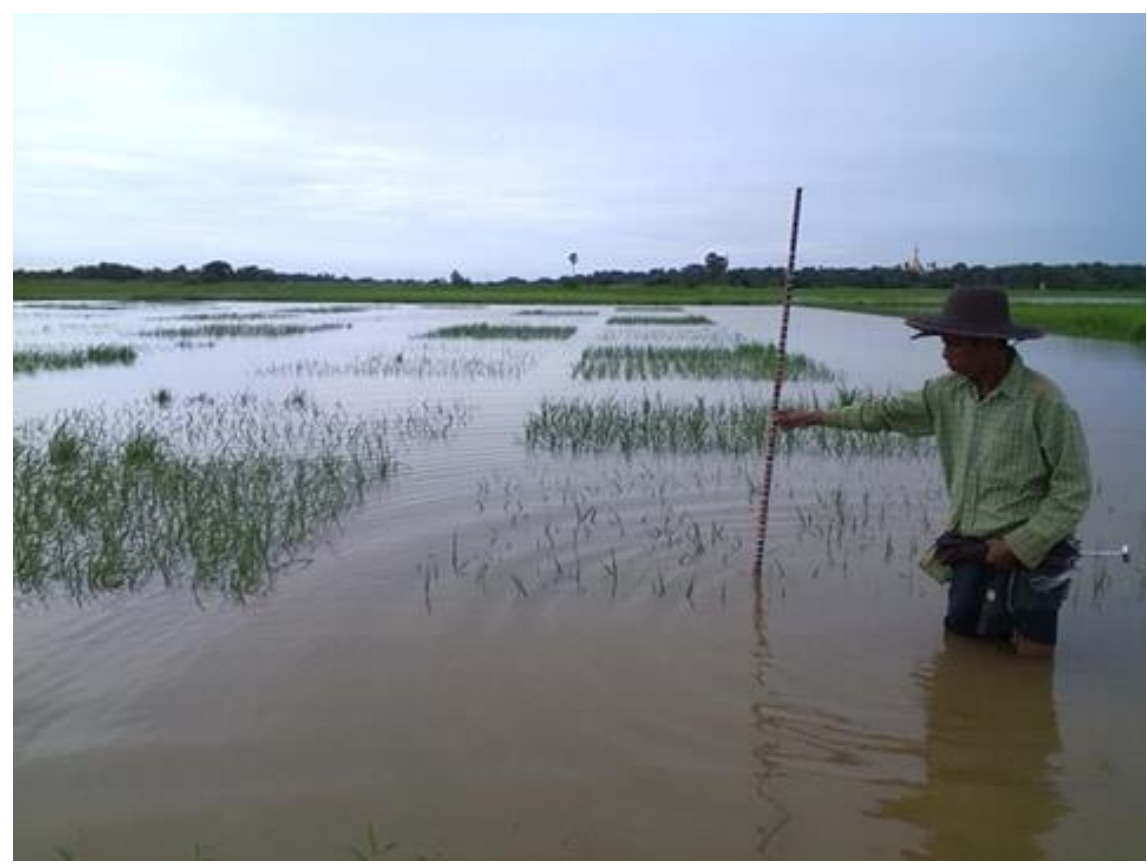

Appendix 2. Experimental field showing different in plant height and maturity time among the treatments

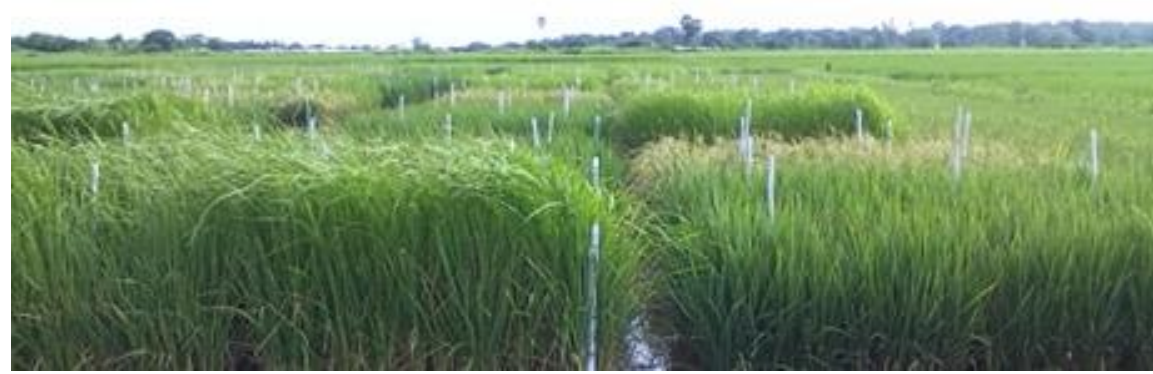

APPLIED ECOLOGY AND ENVIRONMENTAL RESEARCH 17(6):15643-15655.

http://www.aloki.hu • ISSN 15891623 (Print) • ISSN 17850037 (Online)

DOI: http://dx.doi.org/10.15666/aeer/1706_1564315655

(c) 2019, ALÖKI Kft., Budapest, Hungary 